\title{
Molecular phylogeny of Neotropical monogeneans (Platyhelminthes: Monogenea) from catfishes (Siluriformes)
}

\author{
Carlos A Mendoza-Palmero ${ }^{1 *}$, Isabel Blasco-Costa ${ }^{2,3}$ and Tomáš Scholz ${ }^{1}$
}

\begin{abstract}
Background: The phylogenetic relationships of dactylogyrids (Monogenea: Dactylogyridae) parasitising catfishes (Siluriformes) from the Neotropical region were investigated for the first time.

Methods: Partial sequences of the $28 \mathrm{~S}$ rRNA gene of 40 specimens representing 25 dactylogyrid species were analysed together with sequences from GenBank using Bayesian inference, Maximum likelihood and Parsimony methods. Monophyly of dactylogyrids infecting catfishes and the Ancyrocephalinae was evaluated using the Approximately Unbiased test.

Results: The Ancyrocephalinae is a paraphyletic group of species clustering in three main clades as follows: (i) clade A comprising freshwater dactylogyrids from the Holarctic parasitising perciforms clustering together with species (Ameloblastella, Unibarra and Vancleaveus) parasitising Neotropical catfishes; (ii) clade B including species of Dactylogyrus (Dactylogyrinae) and Pseudodactylogyrus (Pseudodactylogyrinae) along with Ancyrocephalus mogurndae, and marine dactylogyrids with cosmopolitan distribution, parasites of scorpaeniforms and perciforms, along with the freshwater Cichlidogyrus and Scutogyrus (infecting African cichlids [Cichlidae]) and (iii) clade C containing exclusively dactylogyrids of siluriforms, freshwater and marine, with Palaearctic, Ethiopian, Oriental and Neotropical distributions; species of Aphanoblastella and Dactylogyridae gen. sp. 4 from the Neotropical region clustering together with species allocated in the Ancylodiscoidinae, along with species of Cosmetocleithrum, Demidospermus and Dactylogyridae gen. spp.

Conclusions: The position of the Ancylodiscoidinae within a larger clade of dactylogyrids (ancyrocephalines) indicates that this subfamily does not represent a natural group. Instead, species allocated to this clade (dactylogyrids of siluriforms along with species of the Ancylodiscoidinae) should be considered as a separate subfamily within the Dactylogyridae. The erection of this taxon requires the search for morphological diagnostic characters in addition to phylogenetic information. A similar strategy should be considered for a new classification of the paraphyletic Ancyrocephalinae. Members of the three clades do not seem to share obvious morphological synapomorphies nor clear patterns in host-parasite associations, zoogeographical distribution or ecology. Clade A should be considered as the Ancyrocephalinae sensu stricto since it includes the type species Ancyrocephalus paradoxus Creplin, 1839. A new subfamily should be proposed to accommodate species currently allocated to Ancyrocephalinae clustering within clade B. Future attempts to propose a new classification of the subfamilies in the Dactylogyridae should include the phylogenetically diverse Neotropical dactylogyrids.
\end{abstract}

Keywords: Phylogeny, Monogenea, Dactylogyridae, Neotropical region, Diversity, Siluriformes, 28S rRNA

\footnotetext{
*Correspondence: cmpamtheus@yahoo.es

${ }^{1}$ Institute of Parasitology, Biology Centre of the Czech Academy of Sciences and Faculty of Science, University of South Bohemia, Branišovská 31, 37005 České Budějovice, Czech Republic

Full list of author information is available at the end of the article
}

\section{Biomed Central}

(c) 2015 Mendoza-Palmero et al.; licensee BioMed Central. This is an Open Access article distributed under the terms of the Creative Commons Attribution License (http://creativecommons.org/licenses/by/4.0), which permits unrestricted use, distribution, and reproduction in any medium, provided the original work is properly credited. The Creative Commons Public Domain Dedication waiver (http://creativecommons.org/publicdomain/zero/1.0/) applies to the data made available in this article, unless otherwise stated. 


\section{Background}

The order Siluriformes, commonly known as catfishes, is a monophyletic group comprising more than 2,800 species with worldwide distribution. About 1,700 species, including undescribed forms, occur in the American continent, mostly in the Neotropical region [1,2]. Catfishes are greatly appreciated by aquarists and many species, especially large pimelodids and doradids, are used for local consumption. Despite their great diversity and economic importance, less than $10 \%$ of catfish species have been studied for metazoan parasites in the Neotropics (see [3-6] and references therein).

The global fauna of monogeneans (Platyhelminthes) of the family Dactylogyridae Bychowsky, 1933 infecting catfishes is very diverse and includes 379 species belonging to 31 genera [7-12]. Almost one half of the genera (14) and about 75 species are distributed only in the Neotropical region. Moreover, Mendoza-Palmero et al. [13] listed many undescribed dactylogyrids (almost $60 \mathrm{spp}$.) from catfishes only from the Peruvian Amazonia. This finding doubles the number of putative dactylogyrid species from catfishes in the Neotropics, thus providing evidence that the current number of nominal species represents only a very small proportion of the actual species richness and diversity of these parasitic flatworms. Given this scenario, it is clear that monogenean fauna, particularly that from the Neotropics, is far from being well known.

Traditionally, monogenean parasites of catfishes are included in the subfamilies Ancylodiscoidinae Gusev, 1961 and Ancyrocephalinae Bychowsky, 1937 within the Dactylogyridae e.g. $[4,8,10]$ and references therein. The classification of these two subfamilies and their phylogenetic relationships within the Dactylogyridae have been a matter of discussion for several decades. The latter subfamily was even raised to the family level as Ancyrocephalidae Bychowsky, 1937 [14]. Kritsky and Boeger [15] reviewed the status of the Ancyrocephalidae sensu Bychowsky and Nagibina [14] based on an analysis of the morphological characters of some of its members. They found no phylogenetic support for the family, suggesting that the Ancyrocephalidae should be considered a junior synonym of the Dactylogyridae and proposed nine subfamilies to be included within this family, namely Anacanthorinae Price, 1967, Ancylodiscoidinae Gusev, 1961, Ancyrocephalinae Bychowsky, 1937, Dactylogyrinae Bychowsky, 1933, Hareocephalinae Young, 1968, Heterotesiinae Euzet and Dossou, 1979, Linguadactylinae Bychowsky, 1957, Linguadactyloidinae Thatcher and Kritsky, 1983, and Pseudodactylogyrinae Ogawa, 1986. Subsequently, Lim et al. [8] reviewed the status of all genera infecting siluriform fishes in the Old World and proposed to raise the Ancylodiscoidinae to the familial level to accommodate 17 genera.
Recent phylogenetic studies based on different molecular markers (e.g., mitochondrial 16S rRNA gene, 18S and $28 \mathrm{~S}$ rDNA regions or internal transcribed spacer of the rRNA gene), have suggested that the subfamily Ancyrocephalinae represents a paraphyletic group, composed of two ecologically divergent clades: (i) freshwater Ancyrocephalinae clustering together with the Ancylodiscoidinae (with species parasitising freshwater catfishes), and (ii) marine Ancyrocephalinae as the sister group of both the Dactylogyrinae and Pseudodactylogyrinae (see [16-19]). However, the monophyly of this group has not been statistically tested in previous studies. Moreover, only species from Europe, North America and Asia have been included so far.

In contrast with the enormous dactylogyrid diversity infecting freshwater catfishes in the Neotropical region, none of these taxa has yet been considered in molecular phylogenetic analyses. Therefore, the aim of our study is to reconstruct, for the first time, the evolutionary history of dactylogyrids infecting catfishes from the Neotropical region based on partial sequences of the $28 \mathrm{~S}$ rRNA gene in order to evaluate the phylogenetic positions of the representatives of Ancylodiscoidinae and dactylogyrids of Neotropical siluriform fishes within Dactylogyridae.

\section{Methods}

\section{Specimen collection}

Fishes were obtained by local fishermen, ornamental fish companies, or purchased at local markets in Iquitos, Loreto Region, Peru (2004-2011) from the following localities: Santa Clara $\left(3^{\circ} 46^{\prime} 59^{\prime \prime} \mathrm{S}, 73^{\circ} 20^{\prime} 32^{\prime \prime W}\right)$, Río Itaya

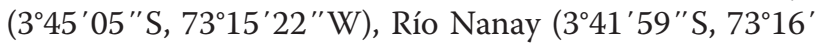

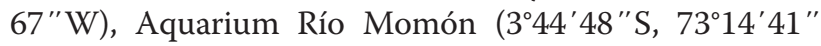
$\mathrm{W})$, Granja $4\left(3^{\circ} 47^{\prime} 30^{\prime \prime} \mathrm{S}, 73^{\circ} 17^{\prime \prime} \mathrm{W}\right)$, and fish market in Iquitos-Belén $\left(3^{\circ} 45^{\prime} 51^{\prime \prime} \mathrm{S}, 73^{\circ} 14^{\prime} 49^{\prime \prime} \mathrm{W}\right.$ ) (all in the Amazon River basin). Additional fish samples were obtained from Lago de Catemaco, Veracruz, Mexico $\left(18^{\circ} 25^{\prime} 01^{\prime \prime} \mathrm{N}\right.$, 95 $\left.06^{\prime} 46^{\prime \prime} \mathrm{W}\right)$, Baia de Antonina, municipality of Antonina,

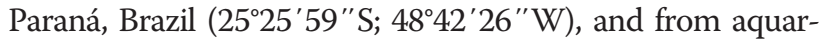
ists in the Czech Republic (see Table 1).

Gills of fish were placed in Petri dishes with tap water and examined for monogeneans under stereomicroscope. Monogeneans were placed in a drop of water on a slide with a coverslip, identified to the species level or to a morphotype based on the data accumulated in previous studies $[13,30]$ with the aid of an optical microscope and preserved in 95\% ethanol for molecular analyses. Entire gill arches of heavily infected fishes were fixed with hot water $\left(\sim 60^{\circ} \mathrm{C}\right)$ and preserved in plastic containers with $95 \%$ ethanol.

\section{DNA extraction, amplification and sequencing}

To ensure the identity of each specimen, either the haptor or the medial part of the trunk of each worm used 
Table 1 List of monogeneans included into phylogenetic analyses

\begin{tabular}{|c|c|c|c|c|c|c|}
\hline Parasite species & Host & Host family & Locality & $\begin{array}{l}\text { No. } \\
\text { isolates }\end{array}$ & $\begin{array}{l}\text { GenBank } \\
\text { ID }\end{array}$ & Reference \\
\hline \multicolumn{7}{|l|}{ Dactylogyridae } \\
\hline \multicolumn{7}{|l|}{ Ancyrocephalinae } \\
\hline Actinocleidus recurvatus & Lepomis gibbosus & Centrarchidae & River Danube, Slovak Republic & 1 & AJ969951 & {$[20]$} \\
\hline Aliatrema cribbi & Chaetodon citrinellus & Chaetodontidae & French Polynesia & 1 & AY820612 & {$[17]$} \\
\hline $\begin{array}{l}\text { Ameloblastella } \\
\text { chavarriai }\end{array}$ & Rhamdia quelen & Heptapteridae & $\begin{array}{l}\text { Lago de Catemaco, Veracruz, } \\
\text { Mexico }\end{array}$ & 2 & $\begin{array}{l}\text { KP056251- } \\
52\end{array}$ & Present study \\
\hline Ameloblastella sp. & Hassar sp. & Doradidae & Aquarium Río Momón, lquitos, Peru & 1 & KP056253 & Present study \\
\hline Ameloblastella sp. 8 & Sorubim lima & Pimelodidae & lquitos, Peru & 1 & KP056254 & Present study \\
\hline Ameloblastella sp. 16 & $\begin{array}{l}\text { Hypophthalmus } \\
\text { edentatus }\end{array}$ & Pimelodidae & Río Nanay, lquitos, Peru & 1 & KP056255 & Present study \\
\hline Ameloblastella sp. 23 & $\begin{array}{l}\text { Hypophthalmus } \\
\text { edentatus }\end{array}$ & Pimelodidae & Río Nanay, lquitos, Peru & 1 & KP056233 & Present study \\
\hline $\begin{array}{l}\text { Ancyrocephalus } \\
\text { morgundae }\end{array}$ & Siniperca chuatsi & Percichthyidae & Wuhan, China & 1 & AY841871 & [21] \\
\hline $\begin{array}{l}\text { Ancyrocephalus } \\
\text { mogurndae }\end{array}$ & Siniperca chuatsi & Percichthyidae & Fuzhou, Fujian Province, China & 1 & DQ157667 & [22] \\
\hline $\begin{array}{l}\text { Ancyrocephalus } \\
\text { paradoxus }\end{array}$ & Sander lucioperca & Percidae & River Morava, Czech Republic & 1 & AJ969952 & [20] \\
\hline Ancyrocephalus percae & Perca fluviatilis & Percidae & Lake Constance, Germany & 1 & KF499080 & [23] \\
\hline $\begin{array}{l}\text { Aphanoblastella } \\
\text { aurorae }\end{array}$ & Goeldiella eques & Heptapteridae & Santa Clara, Iquitos, Peru & 1 & KР056239 & Present study \\
\hline Aphanoblastella sp. 3 & Goeldiella eques & Heptapteridae & Río Nanay, lquitos, Peru & 2 & $\begin{array}{l}\text { KP066237- } \\
38\end{array}$ & Present study \\
\hline Bravohollisia rosetta & Pomadasys maculatus & Haemulidae & Guangdong, China & 1 & DQ537364 & [18] \\
\hline Cichlidogyrus sclerosus & Oreochromis niloticus & Cichlidae & Panyu, Guangdong Province, China & 1 & DQ157660 & [22] \\
\hline Cichlidogyrus tilapiae & Hemichromis fasciatus & Cichlidae & Senegal, Africa & 1 & HQ010029 & [24] \\
\hline Cosmetocleithrum sp. 8 & Hassar orestis & Doradidae & Aquarium Río Momón, lquitos, Peru & 2 & $\begin{array}{l}\text { KP056216- } \\
17\end{array}$ & Present study \\
\hline $\begin{array}{l}\text { Demidospermus } \\
\text { mortenthaleri }\end{array}$ & $\begin{array}{l}\text { Brachyplatystoma } \\
\text { juruense }\end{array}$ & Pimelodidae & Santa Clara, lquitos, Peru & 2 & $\begin{array}{l}\text { KP056245- } \\
46\end{array}$ & Present study \\
\hline Demidospermus sp. 11 & $\begin{array}{l}\text { Brachyplatystoma } \\
\text { vaillantii }\end{array}$ & Pimelodidae & Río Nanay, lquitos, Peru & 1 & KP056235 & Present study \\
\hline Demidospermus sp. 23 & $\begin{array}{l}\text { Brachyplatystoma } \\
\text { vaillantii }\end{array}$ & Pimelodidae & Río Nanay, lquitos, Peru & 1 & KP056236 & Present study \\
\hline Ergenstrema mugilis & Liza ramada & Mugilidae & Ebro Delta, Spain & 1 & JN996800 & {$[19]$} \\
\hline $\begin{array}{l}\text { Euryhaliotrema } \\
\text { perezponcei }\end{array}$ & Lutjanus guttatus & Lutjanidae & Bay Cerritos, Mazatlan, Mexico & 1 & HQ615996 & $\begin{array}{l}\text { Soler-Jiménez et al. } \\
\text { (unpublished) }\end{array}$ \\
\hline $\begin{array}{l}\text { Euryhaliotrematoides } \\
\text { pirulum }\end{array}$ & Chaetodon Iunula & Chaetodontidae & French Polynesia & 1 & AY820618 & {$[17]$} \\
\hline Haliotrema cromileptis & $\begin{array}{l}\text { Epinephelus bleekeri, E. } \\
\text { coioides }\end{array}$ & Serranidae & Nha Trang Bay, Vietnam & 1 & EU523146 & [25] \\
\hline Haliotrema platycephali & Platycephalus indicus & Platycephalidae & Weihai, Shangdong Province, China & 1 & DQ157662 & [22] \\
\hline Haliotrematoides guttati & Lutjanus guttatus & Lutjanidae & Bay Cerritos, Mazatlan, Mexico & 1 & HQ615993 & $\begin{array}{l}\text { Soler-Jiménez et al. } \\
\text { (unpublished) }\end{array}$ \\
\hline Haliotrematoides spinatus & Lutjanus guttatus & Lutjanidae & Pacific Coast, Mexico & 1 & KC663679 & $\begin{array}{l}\text { García-Vázquéz et al. } \\
\text { (unpublished) }\end{array}$ \\
\hline Ligictaluridus pricei & Ameiurus nebulosus & Ictaluridae & River Moldau, Czech Republic & 1 & AJ969939 & {$[20]$} \\
\hline Ligophorus vanbenedenii & Liza aurata & Mugilidae & Ebro Delta, Spain & 1 & JN996802 & [19] \\
\hline Metahaliotrema mizellei & Scatophagus argus & Scatophagidae & Panyu, Guangdong Province, China & 1 & DQ157647 & [22] \\
\hline
\end{tabular}


Table 1 List of monogeneans included into phylogenetic analyses (Continued)

\begin{tabular}{|c|c|c|c|c|c|c|}
\hline Onchocleidus similis & Lepomis gibbosus & Centrarchidae & River Danube, Slovak Republic & 1 & AJ969938 & {$[20]$} \\
\hline Onchocleidus sp. & Lepomis macrochirus & Centrarchidae & Guangzhou, China & 1 & AY841873 & {$[21]$} \\
\hline Protogyrodactylus alienus & Gerres filamentosus & Gerreidae & $\begin{array}{l}\text { Dayawan, Guangdong Privince, } \\
\text { China }\end{array}$ & 1 & DQ157650 & [22] \\
\hline $\begin{array}{l}\text { Protogyrodactylus } \\
\text { hainanensis }\end{array}$ & Therapon jarbua & Terapontidae & $\begin{array}{l}\text { Yangjiang, Guangdong Province, } \\
\text { China }\end{array}$ & 1 & DQ157653 & [22] \\
\hline $\begin{array}{l}\text { Pseudohaliotrema } \\
\text { sphincteroporus }\end{array}$ & Siganus doliatus & Siganidae & Green Island, Australia & 1 & AF382058 & [26] \\
\hline Scutogyrus longicornis & Oreochromis niloticus & Cichlidae & Panyu, Guangdong Province, China & 1 & DQ157659 & [22] \\
\hline Tetrancistrum sp. & Siganus fuscescens & Siganidae & Heron Island, Queensland, Australia & 1 & AF026114 & {$[27]$} \\
\hline $\begin{array}{l}\text { Unibarra } \\
\text { paranoplatensis }\end{array}$ & $\begin{array}{l}\text { Aguarunichthys } \\
\text { torosus }\end{array}$ & Pimelodidae & Santa Clara, lquitos, Peru & 1 & KP056219 & Present study \\
\hline $\begin{array}{l}\text { Vancleaveus } \\
\text { janauacaensis }\end{array}$ & Pterodoras granulosus & Doradidae & Río Itaya, lquitos, Peru & 3 & $\begin{array}{l}\text { KP056240, } \\
47-48\end{array}$ & Present study \\
\hline \multicolumn{7}{|l|}{ Ancylodiscoidinae } \\
\hline $\begin{array}{l}\text { Bychowskyella } \\
\text { pseudobagri }\end{array}$ & Tachysurus fulvidraco & Bagridae & Shaoguan, Guangdong, China & 1 & EF100541 & {$[28]$} \\
\hline Chauhanellus boegeri & Genidens genidens & Ariidae & $\begin{array}{l}\text { Baia de Antonina, municipality of } \\
\text { Antonina, Paraná, Brazil }\end{array}$ & 1 & KP056241 & Present study \\
\hline Chauhanellus sp. & Genidens genidens & Ariidae & $\begin{array}{l}\text { Baia de Antonina, municipality of } \\
\text { Antonina, Paraná, Brazil }\end{array}$ & 1 & KP056242 & Present study \\
\hline Quadriacanthus kobiensis & Clarias batrachus & Clariidae & Guangzhou, China & 1 & AY841874 & {$[21]$} \\
\hline Schilbetrema sp. & Pareutropius debauwi & Schilbeidae & $\begin{array}{l}\text { Aquarium from the Czech Republic, } \\
\text { origin West Africa }\end{array}$ & 2 & $\begin{array}{l}\text { KP056243- } \\
44\end{array}$ & Present study \\
\hline Thaparocleidus asoti & Silurus asotus & Pangasidae & Chongqing City, China & 1 & DQ157669 & {$[22]$} \\
\hline $\begin{array}{l}\text { Thaparocleidus } \\
\text { campylopterocirrus }\end{array}$ & $\begin{array}{l}\text { Pangasianodon } \\
\text { hypophthalmus }\end{array}$ & Pangasidae & Guangzhou, China & 1 & AY841872 & {$[21]$} \\
\hline Thaparocleidus siluri & Silurus glanis & Siluridae & River Morava, Czech Republic & 1 & AJ969940 & [20] \\
\hline Thaparocleidus vistulensis & Silurus glanis & Siluridae & River Morava, Czech Republic & 1 & AJ969941 & {$[20]$} \\
\hline Thaparocleidus sp. & Pangasius sp. & Pangasidae & $\begin{array}{l}\text { Aquarium from the Czech Republic, } \\
\text { origin Asia }\end{array}$ & 2 & $\begin{array}{l}\text { KP056249- } \\
50\end{array}$ & Present study \\
\hline \multicolumn{7}{|l|}{ Dactylogyrinae } \\
\hline Dactylogyrus nanus & Rutilus rutilus & Cyprinidae & River Morava, Czech Republic & 1 & AJ969942 & {$[20]$} \\
\hline $\begin{array}{l}\text { Dactylogyrus } \\
\text { petruschewskyi }\end{array}$ & $\begin{array}{l}\text { Megalobrama } \\
\text { amblycephala }\end{array}$ & Cyprinidae & China & 1 & AY548927 & $\begin{array}{l}\text { Ding and Liao } \\
\text { (unpublished) }\end{array}$ \\
\hline \multicolumn{7}{|l|}{ Pseudodactylogyrinae } \\
\hline $\begin{array}{l}\text { Pseudodactylogyrus } \\
\text { anguillae }\end{array}$ & Anguilla anguilla & Anguillidae & River Danube, Slovak Republic & 1 & AJ969950 & {$[20]$} \\
\hline Pseudodactylogyrus bini & Anguilla anguilla & Anguillidae & Neusiedler Lake, Austria & 1 & AJ969949 & {$[20]$} \\
\hline $\begin{array}{l}\text { Dactylogyridae } \\
\text { gen. sp. } 4\end{array}$ & Ageneiosus vittatus & Auchenipteridae & Río Nanay, lquitos, Peru & 1 & KP056218 & Present study \\
\hline $\begin{array}{l}\text { Dactylogyridae } \\
\text { gen. sp. } 9\end{array}$ & $\begin{array}{l}\text { Platynematichthys } \\
\text { notatus }\end{array}$ & Pimelodidae & Santa Clara, Iquitos, Peru & 5 & $\begin{array}{l}\text { KP056220- } \\
24\end{array}$ & Present study \\
\hline $\begin{array}{l}\text { Dactylogyridae } \\
\text { gen. sp. } 10\end{array}$ & $\begin{array}{l}\text { Platynematichthys } \\
\text { notatus }\end{array}$ & Pimelodidae & Santa Clara, Iquitos, Peru & 3 & $\begin{array}{l}\text { KP056225- } \\
27\end{array}$ & Present study \\
\hline $\begin{array}{l}\text { Dactylogyridae } \\
\text { gen. sp. } 12\end{array}$ & Sorubim lima & Pimelodidae & Iquitos-Belén, Peru & 1 & KP056228 & Present study \\
\hline $\begin{array}{l}\text { Dactylogyridae } \\
\text { gen. sp. } 13\end{array}$ & $\begin{array}{l}\text { Hypophthalmus } \\
\text { edentatus }\end{array}$ & Pimelodidae & Río Nanay, lquitos, Peru & 2 & $\begin{array}{l}\text { KP056229- } \\
30\end{array}$ & Present study \\
\hline $\begin{array}{l}\text { Dactylogyridae } \\
\text { gen. sp. } 18\end{array}$ & $\begin{array}{l}\text { Pseudoplatystoma } \\
\text { fasciatum }\end{array}$ & Pimelodidae & Santa Clara, Iquitos, Peru & 1 & KP056231 & Present study \\
\hline
\end{tabular}


Table 1 List of monogeneans included into phylogenetic analyses (Continued)

\begin{tabular}{|c|c|c|c|c|c|c|}
\hline $\begin{array}{l}\text { Dactylogyridae } \\
\text { gen. sp. } 23\end{array}$ & Platysilurus mucosus & Pimelodidae & Santa Clara, Iquitos, Peru & 1 & KP056232 & Present study \\
\hline $\begin{array}{l}\text { Dactylogyridae } \\
\text { gen. sp. } 26\end{array}$ & $\begin{array}{l}\text { Platynematichthys } \\
\text { notatus }\end{array}$ & Pimelodidae & Santa Clara, lquitos, Peru & 1 & KP056234 & Present study \\
\hline \multicolumn{7}{|l|}{ Diplectanidae } \\
\hline Murraytrema pricei* & Nibea albiflora & Sciaenidae & Panyu, Guangdong Province, China & 1 & DQ157672 & {$[22]$} \\
\hline $\begin{array}{l}\text { Pseudorhabdosynochus } \\
\text { epinepheli* }\end{array}$ & Epinephelus bruneus & Serranidae & $\begin{array}{l}\text { Huidong, Guangdong Province, } \\
\text { China }\end{array}$ & 1 & AY553622 & {$[22]$} \\
\hline $\begin{array}{l}\text { Pseudorhabdosynochus } \\
\text { lantauensis* }\end{array}$ & Epinephelus bruneus & Serranidae & $\begin{array}{l}\text { Huidong, Guangdong Province, } \\
\text { China }\end{array}$ & 1 & AY553624 & {$[22]$} \\
\hline $\begin{array}{l}\text { Sinodiplectanotrema } \\
\text { argyromus* }\end{array}$ & $\begin{array}{l}\text { Nibea albiflora, } \\
\text { Pennahia anea }\end{array}$ & Sciaenidae & Panyu, Guangdong Province, China & 1 & DQ157673 & {$[22]$} \\
\hline \multicolumn{7}{|l|}{ Monocotylidae } \\
\hline Clemacotyle australis* & Aetobatus narinari & Myliobatidae & Heron Island, Australia & 1 & AF348350 & {$[29]$} \\
\hline Decacotyle lymmae* & Aetobatus narinari & Myliobatidae & Heron Island, Australia & 1 & AF348359 & {$[29]$} \\
\hline $\begin{array}{l}\text { Dendromonocotyle } \\
\text { octodiscus* }\end{array}$ & Dasyatis americana & Dasyatidae & Gulf of Mexico, Mexico & 1 & AF348352 & {$[29]$} \\
\hline \multicolumn{7}{|l|}{ Pseudomurraytrematidae } \\
\hline Pseudomurraytrema sp.* & Catostomus ardens & Catostomidae & Snake River, Idaho, USA & 1 & AF382059 & {$[29]$} \\
\hline \multicolumn{7}{|l|}{ Tetraonchidae } \\
\hline $\begin{array}{l}\text { Tetraonchus } \\
\text { monenteron* }\end{array}$ & Esox lucius & Esocidae & River Moldau, Czech Republic & 1 & AJ969953 & {$[20]$} \\
\hline
\end{tabular}

Species sequenced in this study are in bold.

* Species used as outgroups.

for molecular analysis was separated from the body, mounted in a mixture of glycerin and picric acid (GAP) and kept as molecular vouchers (hologenophore, i.e. the voucher specimen from which the molecular sample is directly derived; see [31] for terminology), and deposited in the Parasitological Collection of the Institute of Parasitology (IPCAS), České Budějovice, Czech Republic under the catalogue numbers M-562-M-586. The rest of the body was used for molecular characterization. Genomic DNA was extracted in $200 \mu \mathrm{l}$ of a $5 \%$ suspension of Chelex ${ }^{\mathrm{Ts}}$ in deionized water containing $0.1 \mathrm{mg} / \mathrm{ml}$ proteinase $\mathrm{K}$, followed by incubation at $56^{\circ} \mathrm{C}$ for $3 \mathrm{~h}$, boiling at $90^{\circ} \mathrm{C}$ for $8 \mathrm{~min}$ and centrifugation at $14,000 \mathrm{rpm}$ for $10 \mathrm{~min}$. Polymerase chain reaction (PCR) amplifications were performed in $20 \mu \mathrm{l}$ reactions containing $4 \mu \mathrm{l}$ of extraction supernatant ( 10-20 ng of template DNA), $2 \mathrm{x} \mathrm{MyFi}^{\mathrm{Tm}}$ Mix (Bioline, USA) and $0.4 \mu \mathrm{M}$ of each PCR primer. Partial $28 \mathrm{~S}$ rDNA fragments (D1-D3) were amplified using primers U178 (5'-GCA CCC GCT GAA YTT AAG-3') and L1642 (5'-CCA GCG CCA TCC ATT TTC A-3') [32]. The following thermocycling profile was utilized: denaturation of DNA $\left(95^{\circ} \mathrm{C}\right.$ for $\left.3 \mathrm{~min}\right)$; 34 cycles of amplification $\left(94^{\circ} \mathrm{C}\right.$ for $30 \mathrm{~s}, 56^{\circ} \mathrm{C}$ for $30 \mathrm{~s}$ and $72^{\circ} \mathrm{C}$ for $\left.1: 30 \mathrm{~min}\right)$; and 4 min extension hold at $72^{\circ} \mathrm{C}$. PCR products were purified prior to sequencing using either exonuclease I and shrimp alkaline phosphatase enzymes [33] or gel-excised using High Pure PCR product purification kit ${ }^{\mathrm{TM}}$ (Roche,
Mannheim, Germany). Amplicons were cycle-sequenced from both strands with the PCR primers and L1200R (5'-GCA TAG TTC ACC ATC TTT CGG-3') [34] using ABI BigDye ${ }^{\mathrm{Tm}}$ chemistry (ABI Perkin-Elmer, London, UK), ethanol precipitated and run on an $\mathrm{ABI}$ Prism 3130x1 (Applied Biosystems, Foster City, CA) automated sequencer. Contiguous sequences were assembled and edited using Sequencer ${ }^{\mathrm{TM}}$ (GeneCodes Corp. v. 5) and submitted to GenBank (see accession numbers in Table 1).

\section{Alignment and phylogenetic analyses}

Forty newly generated sequences (900-1,500 bp long) of the partial 28S rDNA fragment of 25 monogenean species, all parasites of catfishes, 23 from the Neotropical region, one from Africa (Schilbetrema sp.) and one from Asia (Thaparocleidus sp.) (see Table 1) were aligned together with 42 published sequences of species belonging to the subfamilies Ancylodiscoidinae, Ancyrocephalinae, Dactylogyrinae and Pseudodactylogyrinae of the Dactylogyridae retrieved from GenBank (see accession numbers in Figure 1 and Table 1). Three sequences of species belonging to the family Monocotylidae of the order Monocotylidea, sister group of the order Dactylogyridea, were used as out groups, together with six sequences of species belonging to families sister to the Dactylogyridae, i.e. Diplectanidae, Pseudomurraytrematidae and Tetraonchidae. Sequences were aligned using default parameters in 


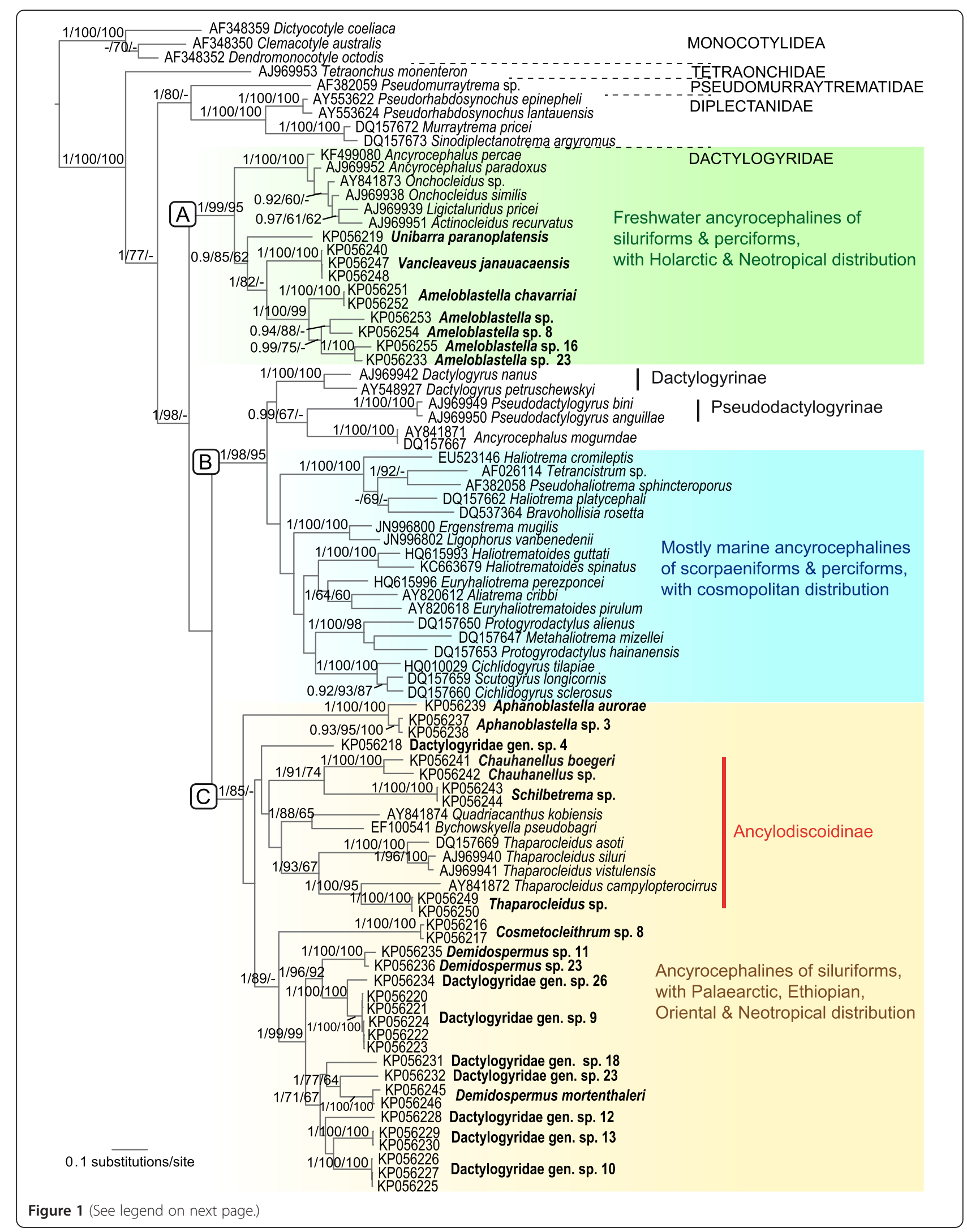


(See figure on previous page.)

Figure 1 Molecular phylogeny of the Dactylogyridae estimated by Bayesian inference using partial sequences of the 28S rRNA gene (695 nt long). Species newly sequenced for this study are in bold. Species belonging to Monocotylidae, Tetraonchidae, Pseudomurraytrematidae and Diplectanidae were used as outgroups. GenBank sequence ID precedes species name. Posterior probabilities and Maximum Likelihood followed by Maximum Parsimony bootstrap support values are given above the branches (posterior probabilities <0.90 and bootstrap values <60 not reported).

MUSCLE implemented in GUIDENCE [35]. Two datasets were created: one included a total of 695 nucleotide positions (full alignment) and another with a total of $489 \mathrm{nt}$ positions, in which positions with a score lower that 0.8 were excluded [36].

Phylogenetic analyses were run under Bayesian inference (BI), Maximum likelihood (ML) and Maximum parsimony (MP) criteria on the two datasets. The nucleotide substitution model GTR $+\Gamma+$ I estimated using jModelTest 2.1.1 $[37,38]$ was used for BI and ML analyses. BI trees were constructed using MrBayes v.3.2 [39], running two independent MCMC runs of four chains for $10^{7}$ generations and sampling tree topologies every $10^{3}$ generations. Burn-in periods were set to $10^{6}$ generations according to the standard deviation of split frequency values $(<0.01)$. A consensus topology and nodal support estimated as posterior probability values [40] were calculated from the remaining trees. $\mathrm{BI}$ and ML analyses were carried out on the computational resource CIPRES [41]. ML analyses were performed with RAxML v.8 [42] using the best result of subtree pruning and regrafting and nearest-neighbour interchange tree search strategies starting with 10 random trees, with a nonparametric bootstrap validation based on 1,000 replicates. MP analysis were conducted in PAUP* [43] using a heuristic search strategy with 100 search replicates, randomaddition taxon sampling, tree-bisection-reconnection and branch-sawpping, with all characters run unordered with equal weights and gaps treated as missing data. Nodal support was estimated by bootstrapping $(n=1,000)$. Topological differences among the BI and ML reconstructions, and an alternative hypothesis enforcing the monophyly of the Ancyrocephalinae were tested against each other using the Approximately Unbiased (AU) test implemented in CONSEL $[44,45]$. BI and ML trees were also tested against two alternative hypotheses enforcing the monophyly of dactylogyrids from the Siluriformes: (1) in exclusively (a monophyletic clade of only dactylogyrids infecting catfishes) and (2) allowing for other species to cluster within the same monophyletic clade. ML branch lengths of the constrained topology were computed in RAxML and the per-site loglikelihood values of both unconstrained and constrained trees were computed in PAUP* using the ML settings described above. Subsequently, $p$ values of the likelihoodbased test were calculated with CONSEL.

\section{Results}

A total of 40 monogenean specimens (36 from the Neotropics, 2 from Africa and 2 from Asia) representing
25 distinct species of monogeneans infecting 17 catfish species (15 Neotropical, 1 African, 1 Asian) were newly sequenced in this study (see Table 1). The specimens identified as Ameloblastella sp., Ameloblastella sp. 8, Ameloblastella sp. 16, Ameloblastella sp. 23, Aphanoblastella sp., Cosmetocleithrum sp. 8, Demidospermus sp. 11, Demidospermus sp. 23, and Dactylogyridae gen. sp. $4,9,10,12,13,18,23$ and 26 represent new species that will be formally described in separate publications.

\section{Phylogenetic relationships within the Dactylogyridae}

Analyses of the two datasets of partial 28S rDNA sequences produced identical topologies, thus we described below the results from the full dataset. For each dataset, the BI, ML and MP analyses yielded phylogenetic trees with mostly similar branching topology and congruent support values. These phylogenetic trees depicted three strongly supported clades (labelled A-C in Figure 1, except clade C in the MP tree) within the Dactylogyridae. However, the relationships among these clades were inconclusive due to the low support for one of the nodes in the three trees. The ML reconstruction (not shown) depicted clades $\mathrm{A}$ and $\mathrm{C}$ as unsupported sister clades, whereas the BI tree (Figure 1) showed clades $B$ and $C$ as unsupported sister clades. In the MP tree (not shown) the three clades formed a polytomy.

In the ML and BI trees, the Ancyrocephalinae appeared as paraphyletic, in which marine and freshwater taxa appeared subdivided in three main clades within the Dactylogyridae. The statistical topology test (AU test) rejected the alternative phylogenetic hypothesis enforcing the monophyly of Ancyrocephalinae ( $p$-value = 0.003 ; rejection at $p$-value $<0.05)$. Neotropical dactylogyrids from siluriforms clustered in two of these three main clades (Figure 1). Dactylogyrids of siluriforms could represent a monophyletic clade if other species infecting freshwater perciforms are included in the clade (as in the ML tree described above in which clades $\mathrm{A}$ and $\mathrm{B}$ containing dactylogyrids from siluriforms are depicted as monophyletic; AU $p$-value $=0.547$ ) but the monophyly of a clade of dactylogyrids infecting siluriforms exclusively was rejected (AU $p$-value $<0.000$ ).

Clade A (see Figure 1) included the freshwater Neotropical dactylogyrids Ameloblastella chavarriai, Ameloblastella sp., Ameloblastella sp. 8, Ameloblastella sp. 16, Ameloblastella sp. 23, Unibarra paranoplatensis and Vancleaveus janauacaensis, the Nearctic species of Actinocleidus recurvatus, Ligictaluridus pricei, Onchocleidus similis and Onchocleidus sp. (for taxonomic discussion of these taxa see 
$[46,47])$, the Palaearctic species of Ancyrocephalus paradoxus and $A$. percae, forming a monophyletic group with strong support. The only monogenean species infecting Nearctic catfishes, Ligictaluridus pricei, did not show a sister relationship with any other species infecting catfishes; in contrast, it grouped with the Nearctic and Palaearctic dactylogyrids infecting fishes of the order Perciformes (Figure 1).

Clade B contained the subfamily Dactylogyrinae represented by the nominotypical Dactylogyrus and the Pseudodactylogyrinae with species of Pseudodactylogyrus clustering together with sequences of specimens identified by Wu et al. [22] and Ding and Liao [21] as Ancyrocephalus mogurndae (Ancyrocephalinae); and representative sequences of marine dactylogyrid species infecting perciforms and scorpaeniforms belonging to Aliatrema, Bravohollisia, Ergenstrema, Euryhaliotrema, Euryhaliotrematoides, Haliotrema, Haliotrematoides, Ligophorus, Metahaliotrema, Protogyrodactylus, Pseudohaliotrema, and Tetrancistrum, together with freshwater species of Cichlidogyrus and Scutogyrus, parasites of African cichlids (Cichlidae) clustering within.

The third strongly supported clade within the Dactylogyridae (clade C) encompassed exclusively parasites of siluriforms from distant zoogeographical areas, i.e. Neotropical, Palaearctic, Oriental and Ethiopian regions. This clade included representative freshwater dactylogyrid taxa from South America (Aphanoblastella aurorae, Aphanoblastella sp. 3, Cosmetocleithrum sp. 8, Demidospermus mortenthaleri, Demidospermus sp. 11, Demidospermus sp. 23 and Dactylogyridae gen. spp.) together with marine and freshwater species allocated to the Ancylodiscoidinae from Eurasia, Africa and South America.

\section{Relationships among dactylogyrids from Neotropical siluriforms}

Species infecting Neotropical siluriforms formed two distinct lineages in clades $\mathrm{A}$ and $\mathrm{C}$ (Figure 1). The first lineage is related to species in clade A (see above) and comprised all sequenced specimens of Ameloblastella sister to Vancleaveus janauacaensis and Unibarra paranoplatensis, parasitic on Aguarunichthys torosus (Pimelodidae) and Pterodoras granulosus (Doradidae), respectively. Ameloblastella was recovered as a strongly supported monophyletic clade with representatives of the type species $A$. chavarriai, a parasite of Rhamdia quelen (Heptapteridae), clustering together with four unidentified putative new species infecting pimelodid catfishes.

The second lineage, clade $\mathrm{C}$, contained species of the Ancylodiscoidinae from Eurasia, Africa and South America clustering together with species parasitising exclusively South American catfishes. Within clade C, the genus Aphanoblastella represented by $A$. aurorae and Aphanoblastella sp. 3, both species infecting the heptapterid Goeldiella eques, was recovered as monophyletic with strong support.

The species allocated in the Ancylodiscoidinae, i.e. Chauhanellus boegeri and Chauhanellus sp., both parasites of the South American ariid Genidens genidens and Schilbetrema sp. of the African schilbeid Pareutropius debauwi, formed a monophyletic clade. Their relationship with species of other genera from Eurasia, i.e. Bychowskyella, Quadriacanthus and Thaparocleidus was not supported, nor with the South American species Dactylogyridae gen. sp. 4 from Ageneiosus vittatus (Auchenipteridae) (see Figure 1).

Cosmetocleithrum, represented by two sequences from Hassar orestis (Doradidae) appeared as a sister taxon to the clade including Demidospermus spp. and numerous unidentified dactylogyrid species parasitising exclusively pimelodid catfishes (Figure 1). Representative species of Demidospermus sp. 11 and Demidospermus sp. 23 appeared as sister species; however, sequences of $D$. mortenthaleri did not cluster together with them.

\section{Discussion}

Our analyses that included 40 novel sequences of 25 species infecting Neotropical, African and Asian catfishes have provided new evidence on the evolutionary history and host-parasite associations of species and genera within the highly diverse family Dactylogyridae. Perhaps the most important finding in our study is the position of the members of the Ancylodiscoidinae among members of the freshwater Ancyrocephalinae, which does not correspond to previous phylogenetic studies [16-19]. The status of the Ancylodiscoidinae and the genera included within has been a matter of discussion since its erection [48]. Kritsky and Boeger [15] included Ancylodiscoidinae into the Dactylogyridae as one of its nine subfamilies. More recently, Lim et al. [8] raised Ancylodiscoidinae to family level suggesting the following diagnostic characteristics: presence of four anchors, 14 marginal hooks and a seminal vesicle of the dactylogyrid-type or blind sac-like type, or both, i.e. two seminal vesicles (usually only one seminal vesicle is present in Ancyrocephalinae). However, two of the proposed diagnostic features are invalid (the presence of four anchors and the number of pair hooks) because they are shared with those of Ancyrocephalinae. In addition, the position and shape of the seminal vesicle is typically difficult to distinguish as it can be confused with the prostatic reservoir (especially in unstained specimens). Therefore, in the light of the morphological similarities and the lack of a phylogenetic support for neither the Ancylodiscoididae sensu Lim et al. [8] nor the Ancylodiscoidinae as proposed by Kritsky and Boeger [15], the 
taxonomic status of these monogenean groups should be revised.

Nevertheless, our results suggest that the existence of a taxon (subfamily or family) of dactylogyrids infecting siluriforms (exclusively or not) seems plausible in two ways. On the one hand, clade $C$, which includes members of the Ancylodiscoidinae clustered with some species parasitising Neotropical catfishes, fits the conception of Gusev [48] and Lim et al. [8] in that parasites of catfishes may represent an independent group within the Dactylogyridae. This clade could be formally erected to the level of subfamily, but morphological synapomorphies should be found to adequately characterise this apparently species-rich and widely distributed group of species whose members parasitise freshwater and marine siluriforms with disjunctive distribution (Neotropical, Ethiopian, Oriental and Palaearctic regions). On the other hand, the two dactylogyrid lineages infecting siluriforms (clade $\mathrm{C}$ and species clustering in clade A) could represent a monophyletic group, as shown by the ML tree and not rejected by the AU test on either ML or BI trees. However, this group would not contain dactylogyrids infecting exclusively catfishes, but also species infecting perciforms (other species in Clade A). Unfortunately, we cannot draw further conclusions from this result since we could not confidently infer the relationship among the three main clades (A, B and $\mathrm{C}$ ). The later hypothesis should be further explored in the future.

Similarly to previous phylogenetic studies [16-19], our results revealed that the present classification of the Ancyrocephalinae is artificial and does not reflect the phylogenetic relationships of this extraordinarily diverse group of dactylogyrid monogeneans. None of the three major clades seem to share any obvious morphological synapomorphies nor some clear patterns in host-parasite associations (although clade $\mathrm{C}$ is restricted to siluriforms), zoogeographical distribution (clade $\mathrm{A}$ in the Holarctic and Neotropics, clade B seemingly cosmopolitan and clade $\mathrm{C}$ in the Palaearctic, Ethiopian, Oriental and Neotropical regions) or environment (except for the exclusively freshwater clade A, whereas species of clades $\mathrm{B}$ and $\mathrm{C}$ parasitise freshwater and marine teleosts). Based on the morphological evidence available to date, it is challenging to establish diagnostic morphological features to characterise individual large clades that include taxa placed in the Ancyrocephalinae. Clade A should be considered as the Ancyrocephalinae sensu stricto due to inclusion of the type species, Ancyrocephalus paradoxus Creplin, 1839, on the nominotypical genus Ancyrocephalus. A new subfamily should be proposed to accommodate species currently allocated to Ancyrocephalinae clustering within clade B, which seems to be more closely related to other subfamilies in the Dactylogyridae than to other members of the Ancyrocephalinae sensu lato. This clade was also recovered as distinct in previous phylogenetic studies [16-19].

Our analyses revealed a close relationship of Ancyrocephalus mogurndae with species of Pseudodactylogyrus, which fully corresponds with results of Mendlová et al. [24]. The sequences of this species provided by Wu et al. [38] and Ding and Liao [39] should be used with caution in future phylogenetic analyses due to their reiterate relationships with members of the Pseudodactylogyrinae.

Three species allegedly belonging to Demidospermus were analysed: the recently described species, D. mortenthaleri, and Demidospermus sp. 11 and sp. 23. All three species parasitise pimelodids of the genus Brachyplatystoma, but they were genetically distant and clustered together with other unidentified dactylogyrids that are morphologically unrelated to species of Demidospermus. It is, therefore, necessary to obtain sequences of the type species, D. anus Suriano, 1983 described from Loricariichthys anus (Loricariidae) from Laguna de Chascomús, Argentina, along with other species of the genus, to adequately circumscribe the species allocated to this genus and their morphological variation.

Monogeneans parasitising the same host species or phylogenetically closely related genera of catfishes from the Neotropical region (see Sullivan et al. [49]) were recovered as phylogenetically distant in the analyses. For instance, Ameloblastella sp. and Cosmetocleithrum sp. 8 in clades $\mathrm{A}$ and $\mathrm{C}$ respectively, parasitising the doradids Hassar orestis and Hassar sp., respectively; Ameloblastella sp. 16 and sp. 23 (clade A) and Dactylogyridae gen. sp. 13 and sp. 10 (clade C), all these four species infecting the pimelodid Hypophthalmus edentatus; Ameloblastella sp. 8 (clade A) and Dactylogyridae gen. sp. 12 (clade C) infecting the pimelodid Sorubim lima; A. chavarriai (clade A) and Aphanoblastella spp. (clade C), parasites of heptapterids of the genera Rhamdia and Goeldiella, respectively. This suggests that independent colonization and host-switching events may account for the extraordinary diversification and high species richness of gill monogeneans occurring in South America [10,13].

\section{Conclusion}

The position of the Ancylodiscoidinae within a larger clade of dactylogyrids (ancyrocephalines) indicates that this subfamily does not represent a natural group. Instead, species allocated to this clade (dactylogyrids of siluriforms along with species of the Ancylodiscoidinae) should be considered as a separate subfamily within Dactylogyridae. The erection of this taxon requires the search for morphological diagnostic characters in addition to phylogenetic information. A similar strategy should be considered for a new classification of the paraphyletic Ancyrocephalinae. Members in each of its three clades do not seem to share obvious morphological 
synapomorphies, nor clear patterns in host-parasite associations, zoogeographical distribution or ecology. Clade A should be considered as the Ancyrocephalinae sensu stricto since it includes the type species Ancyrocephalus paradoxus Creplin, 1839. A new subfamily should be proposed to accommodate species currently allocated to Ancyrocephalinae clustering within clade B. Future attempts to propose a new classification of the subfamilies in the Dactylogyridae should include the phylogenetically diverse Neotropical dactylogyrids.

\section{Competing interests}

The authors declare that they have no competing interests.

\begin{abstract}
Authors' contributions
CAMP, IBC and TS designed the study. CAMP carried out the fieldwork (with the help of TS), collection of material and morphological examination, DNA extraction, sequencing, discussed the results and drafted the manuscript. IBC and CAMP performed the phylogenetic analyses and constructed the phylogenetic trees. TS and IBC discussed the results and contributed to the preparation of the manuscript. Research including field trips in Peru was funded by grant projects of TS. All the authors read and approved the final manuscript.
\end{abstract}

\section{Acknowledgements}

We are indebted to Martin Mortenthaler, Aurora Ramírez Aricara and their staff from Aquarium Río Momón for all support during our campaigns searching for parasites in lquitos, Peru. Specimens of Chauhanellus boegeri and Chauhanellus sp. were kindly donated by W. A. Boeger (Universidade Federal do Paraná, Curitiba, Brazil), specimens of Schilbetrema and Thaparocleidus were provided by Alena Kodádková, Pavla Bartošová and Sneha Patra. Simona Georgieva assisted us during the laboratory work, Jan Brabec provided advice on the AU test, Aneta Kostadinova greatly contributed to improve the manuscript, and Ashlie Hartigan reviewed the English (all of them from the Institute of Parasitology, České Budějovice). Roman Kuchta (Institute of Parasitology, Czech Republic), Alain de Chambrier (Natural History Museum of Geneva, Switzerland), Jesús Montoya-Mendoza (Instituto Tecnológico de Boca del Río, Mexico) and Rogelio Aguilar-Aguilar (Facultad de Ciencias, UNAM, Mexico) helped us during fish examination and parasite collection. Special thanks go to W. A. Boeger for his valuable suggestions to improve the manuscript. This study was financially supported by the Czech Science Foundation (project No. P505/12/G112) and the Institute of Parasitology, BC AS CR, České Budějovice (RVO: 60077344), and forms part of the PhD dissertation of CAM-P, who thanks CONACYT, Mexico (scholarship 192899).

\section{Author details}

${ }^{1}$ Institute of Parasitology, Biology Centre of the Czech Academy of Sciences and Faculty of Science, University of South Bohemia, Branišovská 31, 37005 České Budĕjovice, Czech Republic. ${ }^{2}$ Department of Zoology, University of Otago, P.O. Box 56, Dunedin 9054, New Zealand. ${ }^{3}$ Natural History Museum of Geneva, P.O. Box 6134, CH-1211 Geneva, Switzerland.

Received: 27 December 2014 Accepted: 24 February 2015 Published online: 18 March 2015

\section{References}

1. Nelson JS. Fishes of the World. Mexico: John Wiley \& Sons; 2006.

2. Albert JS, Reis RE. Introduction of Neotropical Freshwater. In: Albert JS, Reis RE, editors. Historical Biogeography of Neotropical Freshwater Fishes. First ed. California: University of California Press; 2011. p. 3-19.

3. Moravec F. Nematodes of freshwater fishes of the Neotropical region. Prague: Academia; 1998

4. Thatcher VE. Amazon fish parasites. Pensoft: Sofia; 2006.

5. Luque $J$, Poulin R. Metazoan parasite species richness in Neotropical fishes: hotspots and the geography of biodiversity. Parasitology. 2007;134:865-78.
6. de Chambrier A, Scholz T, Kuchta R. Taxonomic status of Woodland's enigmatic tapeworms (Cestoda: Proteocephalidea) from Amazonian catfishes: back to museum collections. Syst Parasitol. 2014;87:1-19.

7. Kohn A, Cohen SC. South American Monogenea-list of species, hosts and geographical distribution. Int J Parasitol. 1998;28:1517-54.

8. Lim LHS, Timofeeva TA, Gibson DI. Dactylogyridean monogeneans of the siluriform fishes of the Old World. Syst Parasitol. 2001;50:159-97.

9. Cohen SC, Kohn A. South American Monogenea-list of species, hosts and geographical distribution from 1997 to 2008. Zootaxa. 1924;2008:1-42.

10. Cohen SC, Justo MCN, Kohn A. South American Monogenoidea parasites of fishes, amphibians and reptiles. Rio de Janeiro: Fundação Oswaldo Cruz and Conselho Nacional de Desenvolvimiento Científico e Tecnológico; 2013.

11. Braga MP, Araujo SBL, Boeger WA. Patterns of interaction between Neotropical freshwater fishes and their gill Monogenoidea (Platyhelminthes). Parasitol Res. 2014;113:481-90.

12. Branches B, Domingues MV. A new species of Unilatus (Platyhelminthes: Monogenoidea) from the gills of Leporacanthicus galaxias Isbrücker et Nijssen (Siluriformes: Loricariidae) from Brazil. Acta Parasitol. 2014;59:91-7.

13. Mendoza-Palmero CA, Scholz T, Mendoza-Franco EF, Kuchta R. New species and geographical records of dactylogyrids (Monogenea) of catfish (Siluriformes) from the Peruvian Amazonia. J Parasitol. 2012;98:484-97.

14. Bychowsky BE, Nagibina LF. Revision of Ancyrocephalinae Bychowsky, 1937. Parazitologicheskii Sbornik. 1978;28:5-15 (In Russian).

15. Kritsky DC, Boeger WA. The phylogenetic status of the Ancyrocephalidae Bychowsky, 1937 (Monogenea: Dactylogyroidea). J Parasitol. 1989;75:207-11.

16. Šimková A, Plaisance L, Matějusová I, Morand S, Verneau O. Phylogenetic relatioships of the Dactylogyridae Bychowsky, 1933 (Monogenea; Dactylogyridae): the need for the systematic revision of the Ancyrocephalinae Bychowsky, 1937. Syst Parasitol. 2003;54:1-11.

17. Plaisance L, Littlewood DTJ, Olson PD, Morand S. Molecular phylogeny of gill monogeneans (Platyhelminthes, Monogenea, Dactylogyridae) and colonization of Indo-West Pacific butterflyfish hosts (Perciformes, Chaetodontidae). Zool Scr. 2005;34:425-36.

18. Wu XY, Zhu XQ, Xie MQ, Li AX. The evaluation for generic-level monophyly of Ancyrocephalinae (Monogenea, Dactylogyridae) using ribosomal DNA sequence data. Mol Phylogenet Evol. 2007;44:530-44.

19. Blasco-Costa I, Míguez-Lozano R, Sarabeev V, Balbuena JA. Molecular phylogeny of species of Ligophorus (Monogenea: Dactylogyridae) and their affinities within the Dactylogyridae. Parasitol Int. 2012;61:619-27.

20. Šimková B, Matějusová I, Cunningham CO. A molecular phylogeny of the Dactylogyridae sensu Kritsky \& Boeger (1989) based on the D1-D3 domains of large subunit rDNA. Parasitology. 2006;133:43-53.

21. Ding X-J, Liao X-H. Phylogenetic position of the monogeneans Pseudodactylogyrus, Heteronchocleidus and Trianchoratus inferred from the $5^{\prime}$ terminal sequences of $28 \mathrm{~S}$ rDNA. Acta Zoot Sinica. 2005;30:244-51. In Chinese.

22. Wu XY, Zhu XQ, Xie MQ, Li AX. The radiation of Haliotrema (Monogenea: Dactylogyridae: Ancyrocephalinae): molecular evidence and explanation inferred from LSU rDNA sequences. Parasitology. 2006;132:659-68.

23. Berhrmann-Godel J, Roch S, Brinker A. Gill worm Ancyrocephalus percae (Ergens 1966) outbreak negatively impacts the Eurasian perch Perca fluviatilis L. stock of Lake Constance, Germany. J Fish Dis. 2013;37:925-30.

24. Mendlová M, Pariselle A, Vyskočilová M, Šimková A. Molecular phylogeny of monogeneans parasitising African freshwater Cichlidae inferred from LSU rDNA sequences. Parasitol Res. 2010;107:1405-13.

25. Dang BT, Levsen A, Schander A, Bristow GA. Some Haliotrema (Monogenea: Dactylogyridae) from cultured grouper (Epinephelus spp.) with emphasis on the phylogenetic position of Haliotrema cromileptis. J Parasitol. 2010;96:30-9.

26. Olson PD, Littlewood DTJ. Phylogenetics of the Monogenea - evidence from a medley of molecules. Int J Parasitol. 2002:32:233-44.

27. Mollaret I, Jamieson GMB, Adlard RD, Hugall A, Lecointre G, Chombard C, et al. Phylogenetic analysis of the Monogenea and their relationships with Digenea and Eucestoda inferred from 285 rDNA sequences. Mol Biochem Parasit. 1997:90:433-8.

28. Wu XY, Zhu XQ, Xie MQ, Wang JQ, Li AX. The radiation of Thaparocleidus (Monogenoidea: Dactylogyridae: Ancylodiscoidinae): phylogenetic analyses and taxonomic implications inferred from ribosomal DNA sequences. Parasitol Res. 2008;102:283-8.

29. Chisholm LA, Morgan JAT, Adlard RD, Whittington ID. Phylogenetic analysis of the Monocotylidae (Monogenea) inferred from 285 rDNA sequences. Int J Parasitol. 2001;31:1537-47. 
30. Mendoza-Palmero CA, Scholz T. New species of Demidospermus (Monogenea: Dactylogyridae) of pimelodid catfish (Siluriformes) from Peruvian Amazonia and the reassignment of Urocleidoides lebedevi Kritsky and Thatcher, 1976. J Parasitol. 2011:97:586-92.

31. Astrin JJ, Zhou X, Misof B. The importance of biobanking in molecular taxonomy, with proposed definitions for vouchers in a molecular context. ZooKeys. 2013;635:67-70.

32. Lockyer AE, Olson PD, Littlewood DTJ. Utility of complete large and small subunit rRNA genes resolving the phylogeny of the Neodermata (Platyhelminthes): implications and a review of the cercomer theory. Biol J Linn Soc. 2003;78:155-71.

33. Werle EC, Schneider C, Renner M, Völker M, Fiehn W. Convenient single-step, one tube purification of PCR products for direct sequencing. Nucleic Acids Res. 1994;22:4354-5

34. Littlewood DTJ, Curini-Galletti M, Herniou EA. The interrelationships of Proseriata (Platyhelminthes: Seriata) tested with molecules and morphology. Mol Phylogenet Evol. 2000;16:449-66.

35. Penn O, Privman E, Ashkenazy H, Landan G, Graur D, Pupko T. GUIDANCE: a web server for assessing alignment confidence scores. Nucleic Acids Res. 2010;38(Web Server issue):W23-8.

36. Penn O, Privman E, Landan G, Graur D, Pupko T. An alignment confidence score capturing robustness to guide-tree uncertainty. Mol Biol Evol. 2010;27:1759-67.

37. Guindon S, Gascuel O. A simple, fast and accurate algorithm to estimate large phylogenies by maximum likelihood. Syst Biol. 2003;52:696-704.

38. Darriba D, Taboada GL, Doallo R, Posada D. jModelTest 2: more models, new heuristics and parallel computing. Nat Methods. 2012;9:772.

39. Ronquist F, Teslenko M, van der Mark P, Ayres DL, Darling A, Höhna S, et al. MrBayes 3.2: efficient Bayesian phylogenetic inference and model choice across a large model space. Syst Biol. 2012;61:539-42.

40. Huelsenbeck JP, Ronquist F, Nielsen R, Bollback JP. Bayesian inference of phylogeny and its impact on evolutionary biology. Science. 2001:294:2310-4

41. Miller MA, Pfeiffer W, and Schwartz T. Creating the CIPRES Science Gateway for inference of large phylogenetic trees. In Proceedings of the Gateway Computing Environments Workshop (GCE): 14 November 2010; New Orleans. 2010:1-8.

42. Stamatakis A. RAxML Version 8: A tool for phylogenetic analysis and post-analysis of large phylogenies. Bioinformatics. 2014;30:1312-3.

43. Swofford DL. PAUP*. Phylogenetic Analysis Using Parsimony (*and other Methods). USA: Sinauer Associates; 2002.

44. Shimodaira $\mathrm{H}$. Improving predictive inference under covariate shift by weighting the log-likelihood function. J Stat Plan Infer. 2000;90:227-44.

45. Shimodaira H, Hasegawa M. CONSEL: for assessing the confidence of phylogenetic tree selection. Bioinformatics. 2001:17:1246-7.

46. Beverly-Burton M. Monogenean and Turbellaria. In: Margolis L, Kabata Z, editors. Guide to the parasites of fishes of Canada. Otawa: Department of Fisheries and Oceans; 1984. p. 209.

47. Hoffman GL. Parasites of North American Freshwater fishes. Ithaca: Cornell University Press; 1999.

48. Gusev AV. New subfamily of monogeneans (Monogenoidea). Dokl Akad Nauk SSSR. 1961;139:1480-2 (in Russian).

49. Sullivan JP, Lundberg JG, Hardman M. A phylogenetic analysis of the major groups of catfishes (Teleostei: Siluriformes) using rag1 and rag2 nuclear gene sequences. Mol Phylogenet Evol. 2006;41:636-62.

\section{Submit your next manuscript to BioMed Central and take full advantage of:}

- Convenient online submission

- Thorough peer review

- No space constraints or color figure charges

- Immediate publication on acceptance

- Inclusion in PubMed, CAS, Scopus and Google Scholar

- Research which is freely available for redistribution 